\title{
Formuły paliw etanolowych - wpływ na właściwości eksploatacyjne
}

\begin{abstract}
We wstępie artykułu przedstawiono przyczyny zmian formuł paliw do silników o zapłonie iskrowym, którymi są działania państw i społeczeństw w kierunku ograniczania szkodliwych substancji pochodzących ze spalania paliw oraz uzależnienia od dostaw ropy naftowej. Następnie omówiono rodzaje formuł paliw etanolowych do silników o zapłonie iskrowym, które obecnie są produkowane na świecie. W dalszej części artykułu zaprezentowano zmiany chemicznej formuły paliw do silników o zapłonie iskrowym, w której część węglowodorów jest zastępowana etanolem i/lub eterem etylowo-tert-butylowym. Następnie przedstawiono własne wyniki badań w zakresie wpływu paliw etanolowych na parametry charakteryzujące lotność, która ma bezpośredni wpływ na właściwości eksploatacyjne. W końcowej części pracy zaprezentowano przegląd badań europejskich w zakresie wpływu lotności paliw etanolowych na właściwości eksploatacyjne pojazdu, takie jak emisje, praca silnika w warunkach niskich i wysokich temperatur otoczenia. Konkluzją wynikającą z uzyskanych wyników badań własnych i badań europejskich w zakresie zmian składu frakcyjnego benzyny bezołowiowej E10, kreowanych zawartością etanolu, jest to, że weryfikacja tych zmian w testach hamownianych na obecnej flocie pojazdów potwierdziła przygotowanie nowoczesnych konstrukcji tych pojazdów do bezproblemowej pracy z użyciem paliwa E10. Dalszych weryfikacji w badaniach silnikowych w tym zakresie wymaga paliwo o średniej zawartości etanolu (E20).
\end{abstract}

Słowa kluczowe: etanol, lotność, właściwości eksploatacyjne.

\section{Ethanol fuels formulas - impact on performance characteristics}

In the introduction, the reasons for changing fuel formulas for spark ignition engines, which are the actions of states and societies, to reduce harmful substances from fuel combustion and dependence on oil supplies are presented. The types of ethanol fuels formulas for the spark ignition engines that are currently produced in the world are presented. Hereafter the changes in the chemical formula of fuels for spark ignition engines, in which a part of the hydrocarbons are replaced with ethanol and/or ethyl-tert-butyl ether, are presented. Then our own research results on the impact of ethanol fuels on the volatility, which has a direct influence on the performance characteristics was presented. The final section presents an overview of European research on the volatile effects of ethanol fuels on vehicle performance characteristics such as emissions, engine operation at low and high ambient temperatures. The conclusion resulting from the obtained results of our own research as well as European research on the changes of the unleaded petrol E10 distillation curve, created with ethanol content, is that the verification of these changes in the engine tests on the current fleet of vehicles, confirmed the preparation of modern vehicle designs for trouble-free operation on E10 fuel. Further verifications in the engine tests in this scope require fuel with an average ethanol content (E20).

Key words: ethanol, volatility, engine performance.

\section{Wstęp}

Celem światowej polityki jest dążenie do ograniczania uzależnienia się poszczególnych państw od dostaw ropy naftowej. Jej priorytet stanowi także ochrona zdrowia człowieka i środowiska naturalnego poprzez ograniczanie emisji gazów cieplarnianych, których źródłem jest między innymi transport drogowy.
Należy uznać zatem, że światowa polityka jest obecnie:

- po pierwsze - motorem zmian w tradycyjnych formułach paliw,

- po drugie - prowadzi do mnożenia w świecie rodzajów paliw, które mogą być stosowane albo do tradycyjnych układów napędowych (silnik o zapłonie iskrowym i silnik 
o zapłonie samoczynnym), albo do tychże napędów odpowiednio dostosowanych do paliw alternatywnych.

Jakość paliw ciekłych w aspekcie ich przydatności do napędu pojazdów podlega różnym regulacjom. Wymagania w postaci Światowej Karty Paliw [9] sformułowali producenci silników i pojazdów samochodowych zrzeszeni w stowarzyszeniu ACEA (Association des Constructeurs Européens d'Automobiles). Cel stanowi globalna harmonizacja jakości paliw. W Unii Europejskiej jakość paliw ze względów ochrony zdrowia człowieka i środowiska naturalnego określa dyrektywa FQD (Fuel Quality Directive) (2009/30/WE) z późniejszymi zmianami w postaci dyrektywy ILUC (Indirect Land-Use Change) (2015/1513/UE) [10-11] w powiązaniu z dyrektywą RED (Renewable Energy Directive) (2009/28/WE) [12] oraz dyrektywami dotyczącymi norm emisji EURO. Europejski Komitet Normalizacyjny (CEN) przy współpracy z Komisją Europejską opracowuje normy jakościowe dla paliw uwzględniające postanowienia odpowiednich dyrektyw. Poszczególne kraje członkowskie są zobowiązane do implementacji prawa Unii Europejskiej w tym zakresie oraz implementacji norm jakościowych CEN do polskiego zbioru norm poprzez Polski Komitet Normalizacyjny.

\section{Rodzaje paliw etanolowych do silników o zapłonie iskrowym}

Ze względu na wielkość udziału etanolu (EtOH) w formule paliw do silników o zapłonie iskrowym paliwa te można podzielić na:

- paliwo o małym udziale etanolu - do $10 \%(V / V)$ - benzyna silnikowa E10, w tym E5. Paliwo to jest obecne na rynkach USA (do 15\% (V/V)), Australii, Nowej Zelandii i Europy. W Europie w 2014 roku udział E10 w rynku benzyn wynosił [5]: Francja 32\%, Niemcy 20\%, Finlandia 61\%, Litwa 2,96\%). Jakość paliwa określa obecnie norma EN 228:2012+A1:2017 [16];

- paliwo o średnim udziale etanolu - do $20 \div 25 \%(V / V)$ benzyna silnikowa E20. Paliwo to jest obecne na rynkach Brazylii, Tajlandii i Paragwaju. Jego jakość określają normy krajowe;

- paliwo o dużym udziale etanolu - do $85 \%(V / V)$ - paliwo etanolowe. Paliwo to obecne jest w USA, Brazylii i Europie. W Europie 11 krajów zdecydowało o umieszczeniu tego paliwa na rynku. Są to Szwecja, Francja, Niemcy, Węgry, Czechy, Litwa, Szwajcaria, Holandia, Irlandia, Wielka Brytania i Norwegia. Jakość paliwa etanolowego E85 w Europie określa specyfikacja techniczna CEN/TS 15293:2011 [10].
Wyżej wymienione rodzaje paliw etanolowych są komponowane z wykorzystaniem etanolu bezwodnego, którego jakość w Europie określa norma EN 15376:2014 [14].

Oprócz paliw etanolowych posiadających formułę chemiczną opartą na etanolu bezwodnym w niektórych krajach dystrybuowane są paliwa, do których stosuje się etanol uwodniony. Jakość tego etanolu określają specyfikacje krajowe. Jednym z krajów jest Holandia, gdzie dystrybuowana jest bezołowiowa benzyna silnikowa hE-15, zawierająca do $15 \%$ ( $V / V)$ zawodnionego etanolu [4]. Z kolei w Brazylii jest to paliwo E100, które składa się z etanolu zawierającego 4,9\% (V/V) wody [3].

W Europie, zgodnie z zapisami dyrektyw RED i FQD z późniejszymi zmianami, etanol zawarty w formułach paliw europejskich musi spełniać kryteria zrównoważonego rozwoju, aby można było realizować wyznaczone cele ograniczania emisji GHG (Greenhouse Gas). Według dyrektywy 2015/1513 (ILUC) w 2020 roku biopaliwa I generacji, w tym etanol pochodzący z surowca spożywczego, będą mogły być wykorzystywane do paliw tylko w ilości nie większej niż 7\% końcowego zużycia energii w transporcie, natomiast biopaliwa wyższych generacji, w tym etanol z surowca lignocelulozowego, powinny być już wykorzystywane w ilości minimum 0,5\% tego zużycia.

\section{Formuły chemiczne paliw do silników o zapłonie iskrowym}

Jak wspomniano we wstępie, przyczynami zmian w formule chemicznej benzyny silnikowej jako paliwa do pojazdów o zapłonie iskrowym jest światowa polityka w zakresie ograniczania zanieczyszczenia powietrza atmosferycznego substancjami szkodliwymi pochodzącymi ze spalania paliw ropopochodnych oraz ochrona zdrowia człowieka. Ustalane w związku z tym normy emisji EURO w Europie i Tier w USA wymuszają zmiany w konstrukcji między innymi układów zasilania, komór spalania silnika oraz układów oczyszczania spalin. Z kolei dyrektywy FQD, RED, ILUC (Europa) oraz
Clean Air Act (USA) wymuszają dostosowanie formuły chemicznej paliw do wymogów nowych technologii silników i pojazdów, aby sprostać wymaganiom minimalizacji emisji szkodliwych substancji pochodzących ze spalania paliwa. W tym miejscu warto przypomnieć, jak wyglądała kilkanaście lat temu tradycyjna formuła bezołowiowej benzyny silnikowej. Typowy skład komponentowy i węglowodorowy skład grupowy formuły tradycyjnej benzyny bezołowiowej przedstawiono na rysunku 1 . W węglowodorowej formule chemicznej benzyny bezołowiowej dominują frakcje refor- 
Średnie udziały frakcji benzynowych

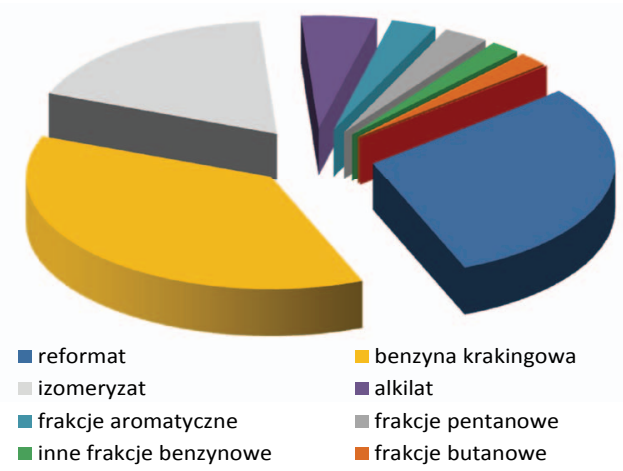

Średnie udziały grup węglowodorowych

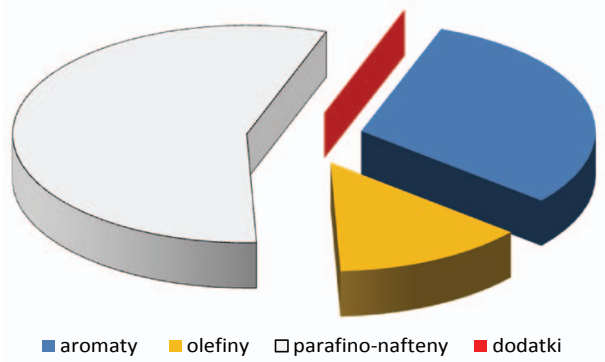

Rys. 1. Tradycyjna formuła węglowodorowej benzyny bezołowiowej

E5 zawierająca maksymalnie 5\% (V/V) EtOH

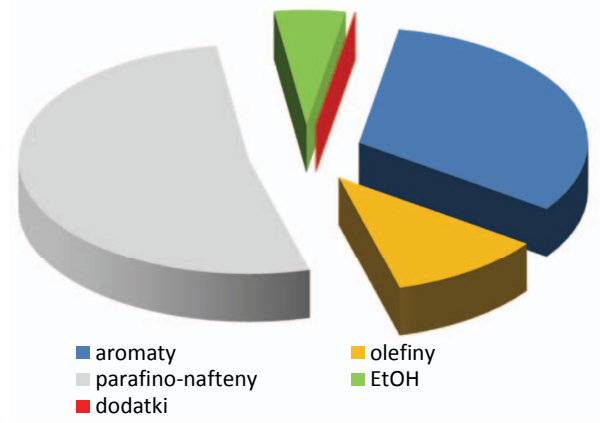

E10 zawierająca maksymalnie 10\% $(V / V)$ EtOH

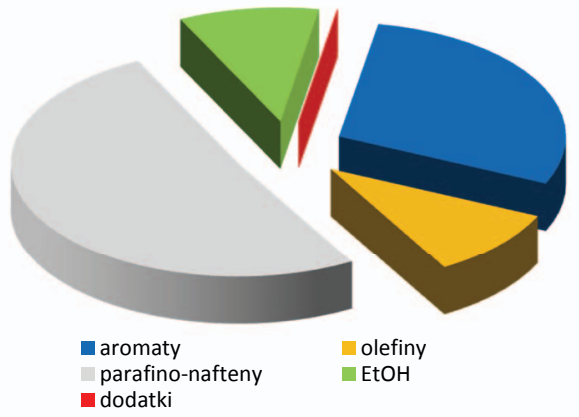

Rys. 2. Formuła benzyny bezołowiowej o małym udziale EtOH

matu, benzyny krakingowej i izomeryzatu; inne frakcje stanowią niewielką część. W podziale na grupy węglowodorów największy udział mają węglowodory parafinowo-naftenowe, następnie aromatyczne, a na końcu olefinowe. W skład benzyny silnikowej wchodzą także pakiety dodatków uszlachetniających w ilości poniżej $0,1 \%(\mathrm{~m} / \mathrm{m})$. Wprowadzenie etanolu w ilości $5 \%(V / V) \mathrm{w}$ formułę tradycyjnej benzyny bezołowiowej powoduje niewielkie zmiany w ilościach poszczególnych grup węglowodorów, ale dodatek etanolu w ilości 10\% $(V / V)$ jest już zauważalny (rysunek 2). Zmniejszeniu ulegają wszystkie trzy podstawowe grupy węglowodorów.

Norma [16] ogranicza zawartości poszczególnych związków tlenowych (między innymi etanolu i eteru etylowo- tert-butylowego) oraz sumaryczną zawartość tlenu. Z tego względu w skład formuły benzyny silnikowej mogą wchodzić równocześnie różne związki tlenowe (alkohole jednowodorotlenowe i etery). Jednak wówczas komponowanie benzyny musi uwzględniać oba powyższe limity. Najczęściej taka właśnie formuła jest realizowana w przypadku bezołowiowych benzyn europejskich. Zawiera ona zarówno etanol, jak i eter etylowo-tert-butylowy (ETBE) i biokomponenty, które służą w poszczególnych krajach Unii Europejskiej do realizacji NCW (Narodowy Cel Wskaźnikowy). Na rysunku 3 przedstawiono obecną typową formułę benzyny bezołowiowej E5, która zawiera zarówno EtOH, jak i ETBE oraz hipotetyczną, jednak możliwą
E5 zawierająca 4\% (V/V) EtOH i 4\% (V/V) ETBE

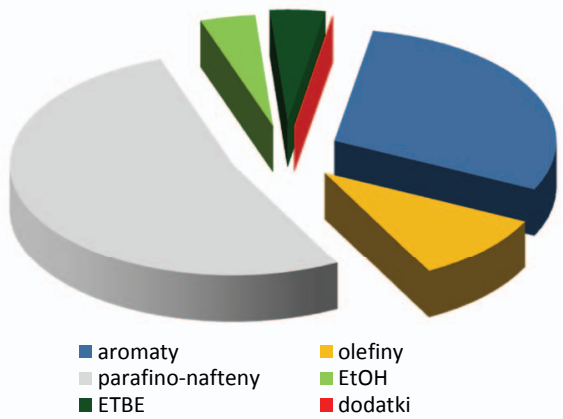

E10 zawierająca 22\% $(V / V)$ ETBE

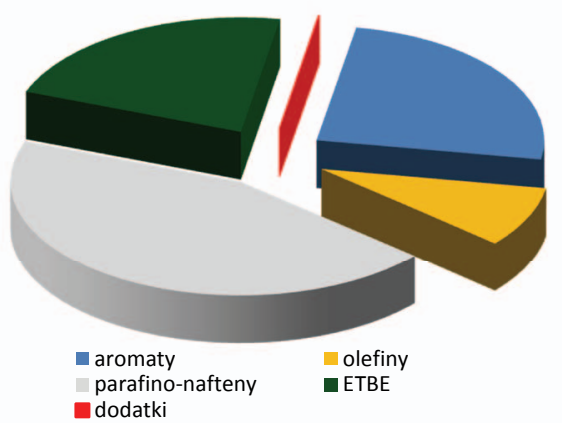

Rys. 3. Formuła benzyny bezołowiowej zawierającej małe udziały EtOH i/lub ETBE 
E85 zawierająca 85\% (V/V) EtOH

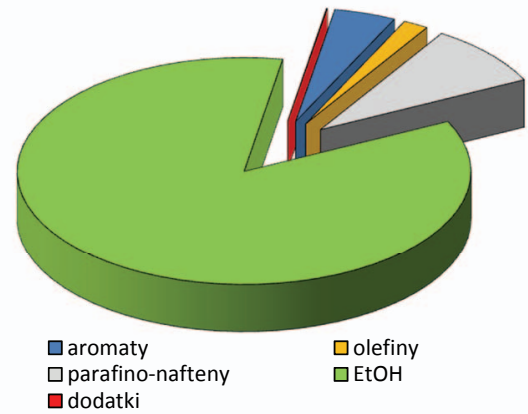

E85 zawierająca 50\% (V/V) EtOH
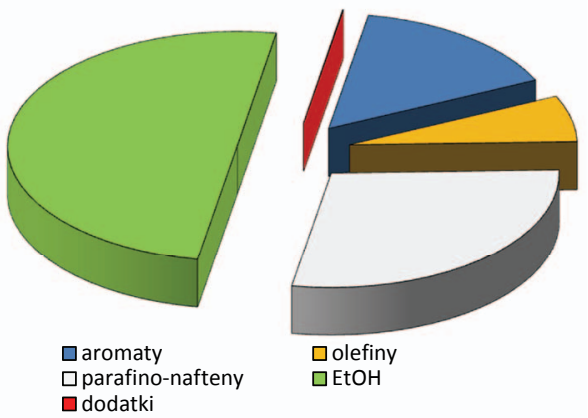

Rys. 4. Formuła paliwa etanolowego E85

do realizacji, formułę benzyny bezołowiowej E10 niezawierającą EtOH, lecz wyłącznie maksymalną dopuszczalną ilość ETBE.

Drugim rodzajem paliwa stosowanego do zasilania pojazdów z silnikiem o zapłonie iskrowym w pojazdach FlexiFuel jest paliwo etanolowe E85. W przypadku jego formuły następuje całkowite odwrócenie proporcji udziałów poszczególnych grup węglowodorowych, co przedstawiono na rysunku 4.
Przegląd powyższych danych prowadzi do wniosku, że wprowadzenie do formuły bazowej węglowodorowej benzyny bezołowiowej związków tlenowych, głównie czystego lub przetworzonego na ETBE etanolu, lub ich mieszaniny powoduje:

- zmniejszenie zawartości związków aromatycznych, olefinowych i parafinowo-naftenowych - proporcjonalnie do wkładu związków tlenowych,

- zwiększenie udziału tlenu wnoszonego przez etanol i ETBE do formuly.

\section{Badania lotności paliw etanolowych}

Obecność alkoholi, głównie etanolu, w formule węglowodorowej benzyny bezołowiowej wpływa na najistotniejsze właściwości eksploatacyjne paliw, takie jak: liczby oktanowe i lotność. O ile jednak w przypadku liczb oktanowych paliw etanolowych (E5, E10, E20, E85), przy zachowaniu dobrych praktyk, raczej nie występuje zagrożenie niedotrzymania wymagań, to w przypadku składu frakcyjnego i prężności par pojawia się silne uzależnienie od zawartości etanolu, które może skutkować przekroczeniami limitów.

Znaczenie poszczególnych parametrów składu frakcyjnego dla właściwej pracy silnika o zapłonie iskrowym przedstawiono na rysunku 5.

Przebadano wpływ koncentracji etanolu w formułach różnych paliw zawierających etanol w ilości do 25\% (V/V) [6, 7]. Na rysunku 6 przedstawiono zmiany parametru E70.

Zamieszczone wyniki wskazują, że etanol wprowadzony do formuły benzyny silnikowej o ilości $5 \div 10 \%(V / V)$ powodował silny wzrost E70. W przypadku średniego udziału etanolu 20\% (V/V) wzrost ten był już mniejszy w porównaniu z E70 oznaczonym dla paliw E5 i E10, chociaż znaczny w porównaniu z wynikiem E70 dla paliwa E0. Uzyskane wyniki dla badanych paliw nie przekroczyły wymagań normy [16]. Na rysunku 7 przedstawiono zmiany parametru E100.

W przypadku parametru E100 etanol wprowadzony do formuły benzyny silnikowej w udziale $5 \div 10 \%(\mathrm{~V} / \mathrm{V})$ powodował niewielki wzrost E100. Jednak przy średnim udziale w ilości 20\% (V/V) etanol silnie oddziaływał, wywołując znaczny wzrost tego parametru. Także w tym przypadku uzyskane wyniki mieściły się w zakresie ujętym w normie [16].

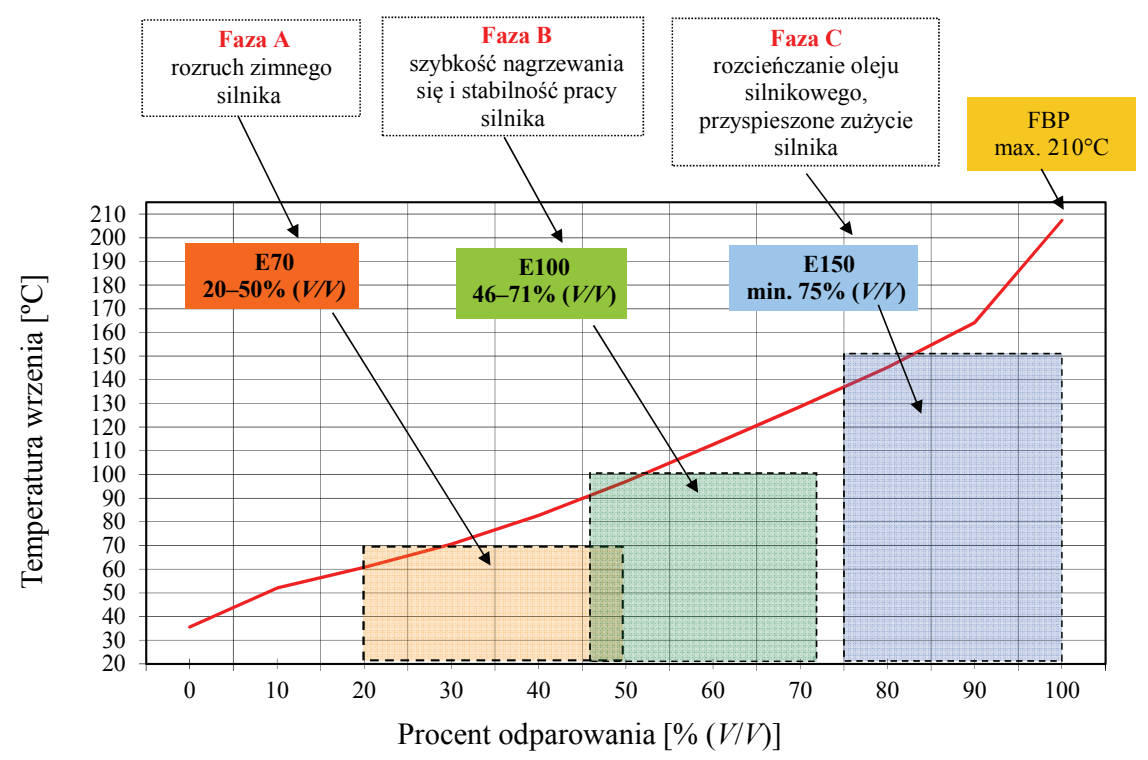

Rys. 5. Znaczenie eksploatacyjne poszczególnych parametrów składu frakcyjnego 


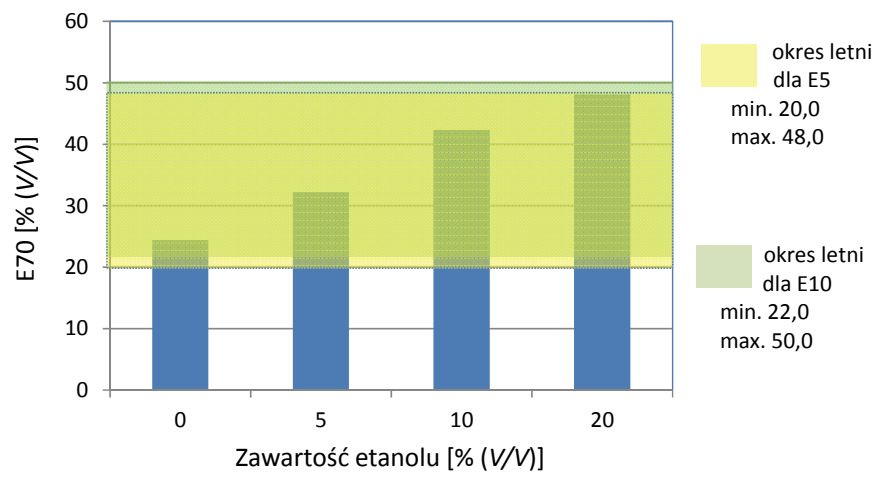

Rys. 6. Wpływ zawartości etanolu w formule paliwa na E70

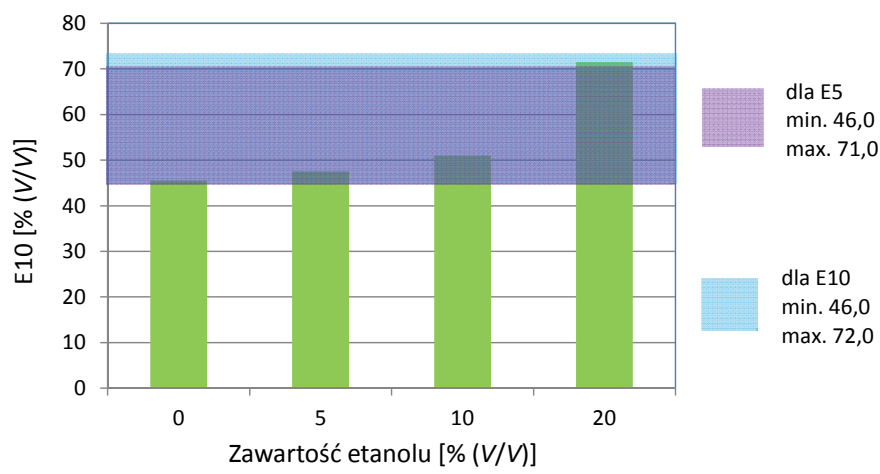

Rys. 7. Wpływ zawartości etanolu w formule paliwa na E100

Parametry składu frakcyjnego oraz prężność par jako jedne z najistotniejszych właściwości eksploatacyjnych są normowane dla benzyny bezołowiowej. Nie normuje się ich w przypadku paliwa etanolowego E85. Istotniejszą rolę odgrywa tu parametr prężności par. W badaniach [6-8] określono wpływ zawartości etanolu w formule paliwa na prężność par benzyny bezołowiowej i paliwa etanolowego. Poniżej, na rysunku 8 , zestawiono uzyskane dane o zmianie prężności par paliw zawierających etanol w przedziale $5 \div 20 \%(V / V)$ i $70 \div 85 \%(V / V)$ w porównaniu z prężnością par benzyny bezołowiowej niezwierającej etanolu. W formule benzyny bezołowiowej daje się zauważyć silny przyrost prężności par przy

Benzyna bezołowiowa

Lato: $45,0 \div 60,0 \mathrm{kPa}$

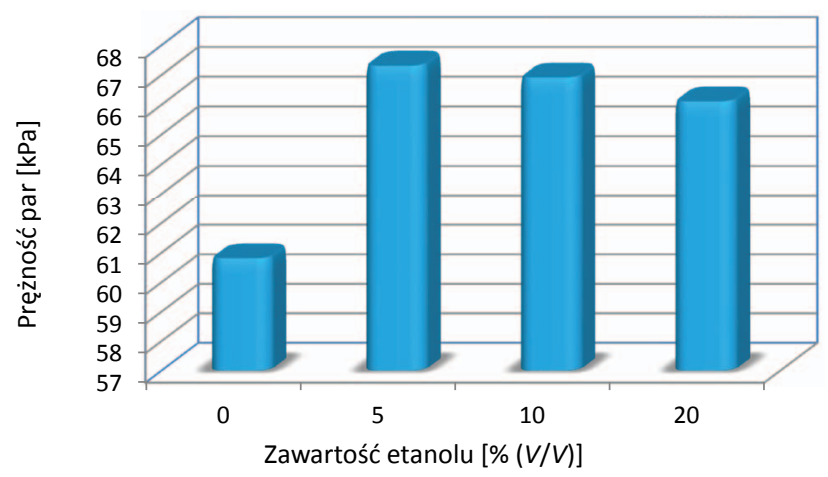

$5 \%(V / V)$ etanolu w paliwie, jednak przyrosty te zaczynają maleć przy wyższej zawartości etanolu. Odwrotna sytuacja ma miejsce przy paliwie etanolowym E85, gdzie przy wzroście udziału etanolu prężność par ulega obniżaniu. Dlatego też w przypadku tego paliwa utrzymanie odpowiednich właściwości eksploatacyjnych reguluje się parametrem prężności par i zawartością etanolu w mieszaninie z benzyną bezołowiową o jakości zgodnej z normą [16].

Większy udział etanolu znacznie zmienia kształt krzywej destylacji, powodując, że większe ilości destylatu uzyskuje się dla niższych temperatur. Mogłoby to stanowić potencjał do zmiany osiągów silnika obecnych i przyszłych pojazdów. Hipoteza taka była podstawą badań $[1,2]$ prowadzonych w programach europejskich, dotyczących analizy wpływu zmian w lotności benzyny bezołowiowej na jej właściwości eksploatacyjne. Celem badań [2] była:

- ocena pracy silnika w warunkach niskich CWD (Cold Weather Driveability) i wysokich HWD (Hot Weather Driveability) temperatur otoczenia oraz emisji spalin i emisji parowania,

- możliwość rekomendacji wartości maksymalnie E70 i maksymalnie E100 do normy EN 228.

Przedmiot badań stanowiły próbki benzyny bezołowiowej E10 [2]. Jedne próbki charakteryzowały się maksymalnymi dopuszczalnymi wartościami E70 i E100 według EN 228, inne wartościami przekraczającymi te limity o $+10 \%(V / V)$ dla E70 i o $+4 \%(V / V)$ dla E100, jeszcze inne wartościami przekraczającymi te limity o $+4 \%(V / V)$ dla E70 i o $+2 \%(V / V)$ dla E100. Prężność par próbek wynosiła dla okresu letniego $60 \mathrm{kPa}$ (maksymalna wartość dopuszczalna) i dla okresu zimowego $100 \mathrm{kPa}$ (maksymalna wartość dopuszczalna). Zakres badań [2] obejmował:

- pomiary emisji CO (Carbon Oxide), THC (Total Hydrocarbon), $\mathrm{NO}_{\mathrm{x}}$ (Nitrogen Oxides), $\mathrm{NMHC}$ (Non-Methane Hydrocarbon), PM (Particulate Matter) - w przypadku silnika z układem wtryskowym DISI (Direct Injection

Paliwo etanolowe E85

Lato: $35,0 \div 60,0 \mathrm{kPa}$

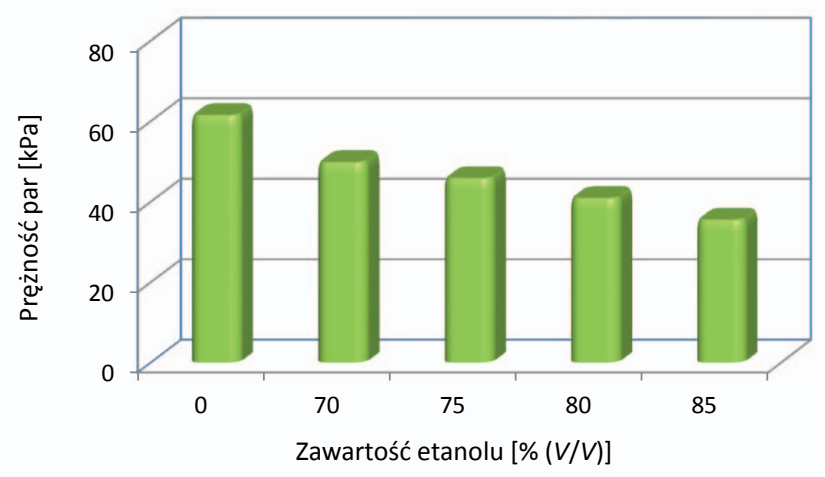

Rys. 8. Wpływ etanolu na prężność par benzyny bezołowiowej i paliwa etanolowego E85 
Spark Ignition), w cyklu NEDC (New European Driving Cycle), w temperaturach $+23^{\circ} \mathrm{C} \mathrm{i}-7^{\circ} \mathrm{C}$,

- pomiary emisji parowania zgodnie z europejską procedurą regulacyjną,

- ocenę możliwości uruchomienia zimnego silnika i pracy na biegu jałowym w temperaturze $-20^{\circ} \mathrm{C}$,

- ocenę pracy silnika w wysokich temperaturach $+40^{\circ} \mathrm{C}$. Badania przeprowadzono w 6 pojazdach klasy średniej $z$ lat 2007-2010 reprezentatywnych dla floty europejskiej, wyposażonych w układ wtryskowy wielopunktowy MPI (Multi-Point Injcetion) (dwa - w układ wtryskowy DISI) [2]. Pojazdy te spełniały wymagania emisji Euro 4 (jeden EURO 5). Były dostosowane do zasilania benzyną bezołowiową zawierającą 10\% $(V / V)$ etanolu.

Wyniki badań zawartych w raporcie [2] wskazały, że:

- parametr E70 (ilość frakcji odparowujących do $70^{\circ} \mathrm{C}-$ faza A na rysunku 5) i prężność par najsilniej oddziałują na pracę silnika pojazdu w warunkach wysokich temperatur otoczenia HWD. Nowoczesne silniki z wtryskiem wielopunktowym MPI są znacznie mniej podatne na problemy z HWD w porównaniu z silnikami gaźnikowymi;

- parametr E100 (ilość frakcji odparowujących do $100^{\circ} \mathrm{C}-$ faza B na rysunku 5) najsilniej oddziałuje na pracę silnika pojazdu w warunkach niskich temperatur otoczenia CWD. Autorzy publikacji [2] omówili problem z pracą silnika w niskich temperaturach (CWD) w przypadku nowoczesnych silników związany z emisją spalin w czasie uruchamiania zimnego silnika. Przy tej samej lotności mieszanin benzyny z etanolem i benzyny węglowodorowej pogarsza się praca silnika pojazdu w warunkach niskich temperatur oto- czenia CWD zasilanego paliwem etanolowym. Według autorów przyczyn należy upatrywać w:

- wysokim cieple parowania etanolu,

- zubożeniu mieszanki paliwo-powietrze,

- pracy silnika w trybie otwartej pętli do czasu (kilkaset sekund) uzyskania minimalnej temperatury roboczej przez układ oczyszczania spalin.

W wyniku przeprowadzonych badań ustalono [2], że:

- wpływ lotności paliw E10 na emisje regulowane NEDC zarówno $\mathrm{w}+23^{\circ} \mathrm{C}$, jak i $\mathrm{w}-7^{\circ} \mathrm{C}$ był niewielki; zaobserwowano wprawdzie wzrost emisji CO dla paliw o wyższej lotności, ale wartości emisji pozostały na poziomach poniżej limitów Euro 4/5,

- silnik w temperaturze $-20^{\circ} \mathrm{C}(\mathrm{CWD})$ łatwo się uruchamiał i stabilna była prędkość obrotowa biegu jałowego, wzrastała emisja $\mathrm{CO}$, ulegała obniżeniu emisja $\mathrm{CO}_{2}$ i $\mathrm{HC}$, - silnik w temperaturze $+40^{\circ} \mathrm{C}$ (HWD) pracował podobnie stabilnie bez względu na właściwości paliw etanolowych. Przeprowadzone prace [2] pozwoliły zarekomendować do nowelizowanej normy EN 228 dla benzyny bezołowiowej wartości graniczne E70 dla poszczególnych warunków klimatycznych i wartości graniczne E100 dla paliwa E10. Znalazło to odzwierciedlenie w nowelizacji normy z 2012 roku [15]. CEN przyjął wartości graniczne dla E70 wyższe o $2 \%(V / V)$ zarówno dla minimum, jak i maksimum, a dla E100 o 1\% $(V / V)$ dla maksimum. W załączniku A normy podano sposób postępowania przy wyznaczaniu dozwolonego bonusu prężności par benzyny z etanolem w okresie letnim, w przypadku, gdy dany kraj UE uzyska ocenę Komisji Europejskiej w tym względzie.

\section{Podsumowanie}

Kierunki rozwoju paliw silnikowych precyzuje wiele dokumentów i aktów prawnych, tworzonych na skutek rosnącej świadomości społeczeństw w zakresie ochrony zdrowia człowieka i środowiska naturalnego. W związku z tym formuła chemiczna finalnego produktu sukcesywnie ulega ewolucji, w celu dostosowania do wymagań konstrukcyjnych pojazdów, tak aby w efekcie zminimalizować emisję szkodliwych substancji powstających podczas spalania takiego paliwa. Badania w tym zakresie niosa wkład w wyznaczanie granic parametrów jakościowych, co znajduje odzwierciedlenie w specyfikacjach jakościowych, a następnie przekłada się na rynkową jakość produktu. Konkluzją wynikającą zarówno z uzyskanych wyników badań własnych, jak i badań europejskich w zakresie zmian składu frakcyjnego benzyny bez- ołowiowej E10, kreowanych zawartością etanolu, jest to, że weryfikacja tych zmian w testach hamownianych na obecnej flocie pojazdów potwierdziła przygotowanie nowoczesnych konstrukcji tych pojazdów do bezproblemowej pracy z użyciem paliwa E10. Dalszych weryfikacji w badaniach silnikowych w tym zakresie wymaga benzyna bezołowiowa o średniej zawartości etanolu (E20), która w przyszłości ma zastąpić paliwo E10. Opracowanie europejskiej specyfikacji jakościowej dla E20 gwarantuje bowiem, że jakość paliwa jest wynikiem konsensusu pomiędzy jego producentem i producentem pojazdu, a w konsekwencji będzie ono akceptowalne przez użytkownika. Benzyna bezołowiowa nadal pozostanie jednym z dwóch głównych paliw napędowych do pojazdów, pomimo że jej skład chemiczny będzie inny niż obecnie. 


\section{Literatura}

[1] Ethanol/petrol blends: volatility characterisation in the range 5-25 vol\% ethanol. TREN/D2/454-2008-SI.2.522.698 (Final Report). Brussels: EU Commission; https://ec.europa.eu/ energy/sites/ener/files/documents/2010_bep525_final_report. pdf (dostęp: czerwiec 2017).

[2] Gasoline volatility and vehicle performance; https://www. concawe.eu/wp-content/uploads/2017/01/rpt_12-2-201200657-01-e.pdf (dostęp: czerwiec 2017).

[3] Henry J. Jr.: Flex Fuel Vehicles in Brazil. ANFAVEA, Energy \& Environment Affairs Commission, Brasília 22.03.2013; http://www.globalbioenergy.org/fileadmin/user_upload/gbep/ docs/2013 events/GBEP_Bioenergy_Week_Brasilia_18-23 March_2013/4.5_JOSEPH.pdf (dostęp: czerwiec 2017).

[4] Keuken H.: Corrosion issues of ethanol blends and the effect of water. ABLCNext Conference - San Francisco, Afternoon Track B - Ethanol, Diesel and Jet Fuels, 11.11.2014; http:/ www.heblends.com/media/PDCABLCNextPresentationEthanolWater.pdf (dostęp: czerwiec 2017).

[5] Overview of the biofuel policies and markets across the EU-28. e-PURE, czerwiec 2016.

[6] Pałuchowska M., Haduch B.: Aspekty wprowadzania średniego poziomu zawartości etanolu do benzyny silnikowej. Czesśś 2. Nieaddytywny wptyw etanolu na lotność. Nafta-Gaz 2016, nr 9, s. 755-760, DOI: 10.18668/NG.2016.09.11.

[7] Pałuchowska M., Rogowska D.: Wptyw bioetanolu na nieaddytywne wtaściwości benzyny silnikowej. Nafta-Gaz 2009, nr 1, s. 21-28.

[8] Rogowska D.: Problem nieeadytywnych efektów mieszania dla parametru ,prężność par" $w$ trakcie blendingu biopaliwa E85. Nafta-Gaz 2010, nr 3, s. 211-215.

[9] Worldwide Fuel Charter, Fifth Edition, wrzesień 2013; www. acea.be (dostęp: czerwiec 2017).

\section{Akty prawne i normatywne}

[10] CEN/TS 15293:2011 Automotive fuels - Ethanol (E85) automotive fuel-Requirements and test methods.
[11] Dyrektywa Parlamentu Europejskiego i Rady (UE) 2015/1513 $z$ dnia 9 września 2015 r. zmieniająca dyrektywę 98/70/WE odnoszaca się do jakości benzyny i olejów napędowych oraz zmieniajaca dyrektywę 2009/28/WE w sprawie promowania stosowania energii ze źródeł odnawialnych.

[12] Dyrektywa Parlamentu Europejskiego i Rady 2009/28/WE $z$ dnia 23 kwietnia 2009 r. w sprawie promowania stosowania energii ze źródet odnawialnych zmieniajaca $i$ w następstwie uchylajaca dyrektywy 2001/77/WE oraz 2003/30/WE.

[13] Dyrektywa Parlamentu Europejskiego i Rady 2009/30/WE z dnia 23 kwietnia 2009 r. zmieniająca dyrektywę 98/70/WE odnoszaca się do specyfikacji benzyny i olejów napędowych oraz wprowadzajaca mechanizm monitorowania i ograniczania emisji gazów cieplarnianych oraz zmieniająca dyrektywę Rady 1999/32/WE odnoszaca sie do specyfikacji paliw wykorzystywanych przez statki żeglugi śródlądowej oraz uchylajaca dyrektywe 93/12/EWG.

[14] EN 15376:2014 Automotive fuels - Ethanol as a blending component for petrol - Requirements and test methods.

[15] EN 228:2012 Automotive fuels - Unleaded petrol - Requirements and test methods.

[16] EN 228:2012+A1:2017 Automotive fuels - Unleaded petrol-Requirements and test method.

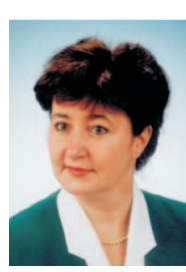

Dr inż. Martynika PAŁUCHOWSKA

Główny specjalista badawczo-techniczny

w Zakładzie Paliw i Procesów Katalitycznych.

Instytut Nafty i Gazu - Państwowy Instytut Badawczy

ul. Lubicz 25 A

31-503 Kraków

E-mail: martynika.paluchowska@inig.pl 